\title{
RESEARCH THE IMPACT OF FDI ON SOME MACROECONOMIC INDICATORS IN BOSNIA AND HERZEGOVINA BY USING OF PROGRAM IBM SPSS STATISTICS
}

\author{
Milan Šušić \\ University of Business Studies Banja Luka, Faculty of Business and Financial Studies, \\ Bosnia and Herzegovina \\ i.susic51@gmail.com
}

\section{Original Scientific Paper doi:10.5937/jouproman6-18224}

\begin{abstract}
It is known that the economic stability and economic development of each economy depends on the free movement of capital. The international movement of capital has its balance of payment when capital export represents economic surplus in relation to consumption of the national economy and the import of capital represents an increase of consumption in regard to the output of a national economy. The paper is analyzed of the influence of foreign direct investment (FDI) on economic growth of the host country, among other things, is emphasized in the function of the achieved phase of its economic development. The aim of this paper refers to an attempt to indicate the significance and the role of FDI as well as the importance of attracting foreign direct investment in $\mathrm{B} \& \mathrm{H}$ and the determination of the effects of FDI on the economy of $\mathrm{B} \& \mathrm{H}$. We will try to prove it, ie to determine the degree of impact of FDI on some macroeconomic indicators in B\&H (GDP, import, export, unemployment) by using IBM SPSS v.22 statistical analysis program (model) and applying the methods,calculating coefficients of correlation and regression analysis. In other words, we will determine the analytical expression used to describe a statistical relationship of these macroeconomic categories.
\end{abstract}

Key words: Macroeconomic factors, GDP, regression and correlation, employment, economic development, investments, capital.

\section{INTRODUCTION}

According to the classic definition, foreign direct investment (FDI) means investing in a newly established company (institution) or investing in an existing domesticcompany (institution), which can be in things, rights and money.
The International Monetary Fund (IMF) defines foreign direct investment (FDI) as a category of international investment that reflects a phenomenon when a resident located in a single country - a foreign direct investor or a parent company - obtains permanent benefits over an enterprise that is a resident of another country - an FDI enterprise or enterprise affiliate or foreign affiliate.

Foreign direct investment can be defined as investments undertaken by a direct investor from a particular country in order to establish a lasting interest in a company resident in another country or according to the OECD: Foreign direct investment can be defined as investments undertaken by a direct investor from a particular country in order to establish a lasting interest in a company resident in another country. FDIs are defined as investments made with the intention to achieve a lasting interest in managing the company in which it is invested, at least $10 \%$ of the votes in the governing (According to World Bank) or voting structure or according to UNCTAD (United Nations Conference on Trade and Development) as investments that imply a long relationship with a lasting interest and control resident company of a country in a company resident company resident in another country (According to UNCTAD). 
The paper deals with the conditions and motives of foreign direct investm The positive results of the inflow of foreign direct investment in $\mathrm{BiH}$ should be shown by increasing and changing GDP, production structure, market openness and an increase in the employment rate.

\section{TERMS AND MOTIVES OF FOREIGN INVESTMENT}

We note that foreign direct investment in global circumstances exceeds pure financial investment and encompasses the real sector of production (Spulber, D.F. 2007). This form of investment represents such a form of transfer of capital, which is realized by direct investment abroad in the form of an entrepreneurial investment. By investing in an existing production system or a new company abroad, the investor reserves the right to manage and control the enterprise in which he invests proportionally invested capital. The primary motive for taking over control over ownership for investors is gaining profit and winning new markets. However, foreign direct investments affect economic growth and through the increase in investment rates, efficiency gains, through the transfer of knowledge and technology.

The realization of foreign investment implies the import of foreign accumulation, which creates the possibility for investments to be higher than domestic accumulations and that increases the rate of economic growth. Reflections of an increased rate of economic growth are visible in a more complete and efficient use of domestic resources. Foreign capital hires domestic labor, that is, it reduces unemployment which is one of the biggest problems in transition countries, including B\&H. FDI has an important impact on economic growth and development of transition countries. Previous experiences show that foreign investment has had a significant role in structural changes of production and import in the countries benefiting from these funds. For countries that have difficult access to the international capital market, FDI represents a 'vent' for using foreign assets. Investigated from the temporal perspective, FDI falls into the longterm flow of capital. According to the economic criterion, i.e. long-term movement of capital is realized within the framework of the loan and capital investment. The aims of international movements of long-term capital are determined by the possibilities and needs of investment on an international scale as well as economic and political relations in the world. International capital movement is manifested in two forms. These forms are: 1) portfolio investment and 2) direct investment.

A significant form of foreign direct investment in developing countries is greenfield investment. They involve raising completely new drives, where capital is imported, technology, a new way of controlling and managing. The strategy for building new plants is most effective for investors when entering a new market where a product or service is not yet produced. On the other hand, for the country of the recipient of "greefield" investment, the most important effects are the import of modern technology, job creation, increased competition and the introduction of new ways of doing business.

Regarding the perspective of foreign direct investment in Bosnia and Herzegovina, it should be pointed out that globalization is striving to support foreign direct investment wherever there is a favorable economic environment. Bearing in mind that the process of integration of the world economy is related to the progress in the flow of foreign direct investment inflows, it can be expected that the general direction of movement will be liberalization (Stiglitz, J.E. at al. 2016). 
In contrast to the earlier inflow of foreign direct investment, which often used inefficient business in developing countries, the inflow of foreign direct investment in global circumstances is geared towards efficient production for the global and the world market.

Arguments in favor of foreign investments are largely derived from the analysis of determinants of economic growth according to neoclassical theory and the new growth theory. Foreign direct investment is seen as a way of filling the gap between domestic savings, foreign exchange, government revenue, and human capital capabilities, and the desired level of those resources needed to achieve growth and development goals. Therefore, the first and most commonly mentioned contribution of foreign investment to the development of their role in filling the gap in resources between targeted or desired investments and local mobilization of savings. The second contribution is to fill the gap between the targeted needs for foreign exchange and those arising from net export earnings. The third gap, which is said to be filled with foreign investments, is the gap between targeted government tax revenues and taxes collected. The fourth contribution is to reduce the gap in management, entrepreneurship, technology and knowledge.

\section{FOREIGN DIRECT INVESTMENT IN BOSNIA AND HERZEGOVINA}

The Volume and quality of investment realized by economic entities are crucial for sustainable economic growth and development. However, retained earnings of enterprises and their own accumulation are often insufficient for major investments. Therefore, an enterprise will find additional external sources of financing. One of the possible sources of investments is foreign direct investment as a special form of financing. Foreign direct investment in the transition countries of Central and Eastern Europe has been shown as a more stable source of financing than any other flow of foreign capital usually without generating debt in a foreign currency.

The special significance of foreign direct investment for Southeastern European countries, including $\mathrm{B} \& \mathrm{H}$, arises from manufacturing and organizational knowledge (know-how) of fore-ign companies, which is undoubtedly important in the restructuring transition economies intended to develop a more competitive frame-work. Foreign direct investment plays one of the key roles in creating sustainable economic growth in $\mathrm{B} \& \mathrm{H}$. Hence, foreign direct inve-stment attraction becomes one of the objectives aiming at strengthening the economic sector.

Expansion of investment activities would enable an increase of production base which is necessary for generating economic development. Foreign capital attraction would profile national economy through expansion of the product range for export. In fact, it is well known that many investors own chains of distribution and sale of the products that could be made in $\mathrm{B} \& \mathrm{H}$. Foreign direct investment is one of the prerequisites for maintaining and increasing production which would lead to an increase in export.

In the case of $\mathrm{BiH}$ (Table 1), the inflow of foreign direct investments was shown, amounting to $\mathrm{KM} 5,578$ billion in the period from 2007 to 2012, while FDI inflows amounted to KM 1,641 billion in the period 2009-2012. 
Foreign direct investments in 2011 amounted to 428 million $\mathrm{KM}$, which represents a decrease of 3.0 million KM compared to 2010, when the total inflow of FDI amounted to 431.0 million KM. Foreign direct investment inflows in 2012 amounted to KM 430.39 million and recorded a slight increase of $0.5 \%$ compared to 2011. FDI inflows from 2013 to 2017 amounted to KM 2,282 billion, and the increase in 2017 was $64 \%$ compared to 2016. In Bosnia and Herzegovina, as of 2010, we have a steady GDP growth annually to date.

In 2014, GDP had a growth rate of $0.6 \%$, which is constantly increasing on an annual basis, and in 2017, the growth rate was $4.88 \%$ annually, which indicates a slight growth of the economy in Bosnia and Herzegovina after the fall in 2009 year.

Table 1.: Movements of macroeconomic indicators (FDI and GDP) in B\&H in the period of 2007-2017 (Author 2018)

Regression rights in the observed period for FDI have a positive direction and constant growth (Figure 1).

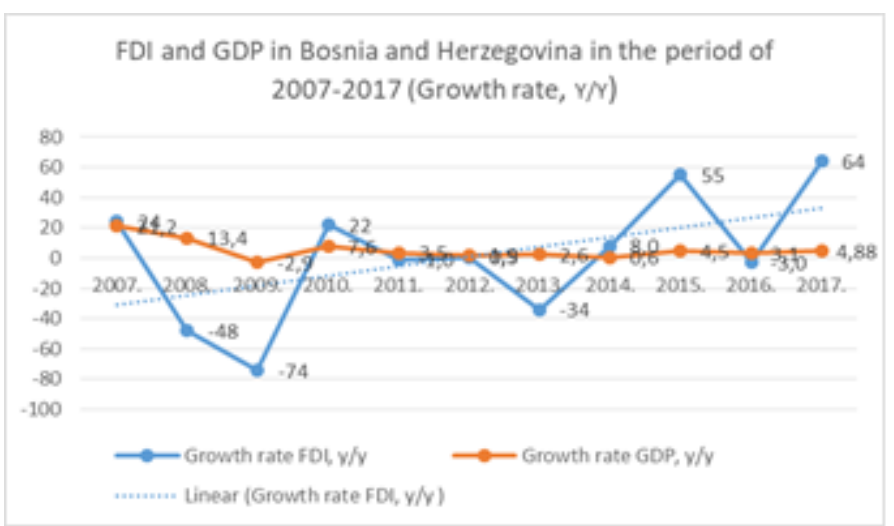

Figure 1.: FDI and GDP in Bosnia and Herzegovina in the period of 2007-2017 (Growth rate, $\mathrm{y} / \mathrm{y})$

(Author 2018)

\section{RESEARCH THE IMPACT OF FDI ON SOME MACROECONOMIC INDICATORS IN BOSNIA AND HERZEGOVIN}

Positive results of foreign direct investment inflows should be shown in increasing and changing GDP, manufacturing structure, openness of the market and increasing the employment rate as well. However, foreign direct investment can cause negative consequences to the host economy because of their sector structure changes. This refers to a decline in employment which is followed by the dismissal of employees due to increased productivity. Movements of some macroeconomic indicators in Bosnia and Herzegovina are presented in the following table 2 .

Table 2.: Movements of macroeconomic indicators in B\&H in the period of 2007-2017, (Agency for Statistics of BiH 2007-2017, http://www.bhas.ba/, Author 2018.)

\begin{tabular}{|c|c|c|c|c|}
\hline Year & $\begin{array}{c}\text { FDI } \\
(\mathrm{mil} . \mathrm{KM})\end{array}$ & $\begin{array}{c}\text { Growth rate } \\
\mathrm{y} / \mathrm{y}\end{array}$ & $\begin{array}{c}\text { GDP } \\
(\mathrm{mil} . \mathrm{KM})\end{array}$ & $\begin{array}{c}\text { Growth } \\
\text { rate y/y }\end{array}$ \\
\hline 2007. & 2.600 & 24 & 21.836 & 21,2 \\
\hline 2008. & 1.337 & -48 & 24.759 & 13,4 \\
\hline 2009. & 352 & -74 & 24.051 & $-2,9$ \\
\hline 2010. & 431 & 22 & 25.886 & 7,6 \\
\hline 2011. & 428 & $-1,0$ & 26.798 & 3,5 \\
\hline 2012. & 430 & 0,5 & 27.308 & 1,9 \\
\hline 2013. & 284 & -34 & 28.027 & 2,6 \\
\hline 2014. & 306 & 8,0 & 28.189 & 0,6 \\
\hline 2015. & 473 & 55 & 29.462 & 4,5 \\
\hline 2016. & 461 & $-3,0$ & 30.389 & 3,1 \\
\hline 2017. & 758 & 64 & 31.871 & 4,88 \\
\hline
\end{tabular}




\begin{tabular}{|c|c|c|c|c|c|}
\hline Year & $\begin{array}{c}\text { FDI } \\
\text { (mil. } \\
\text { KM) }\end{array}$ & $\begin{array}{c}\text { GDP } \\
\text { (mil. KM) }\end{array}$ & $\begin{array}{c}\text { Export } \\
\text { (mil. KM) }\end{array}$ & $\begin{array}{c}\text { Import } \\
\text { (mil. KM) }\end{array}$ & $\begin{array}{c}\text { Number } \\
\text { of } \\
\text { unemploy. }\end{array}$ \\
\hline 2007. & 2.600 & 21.836 & 5.937 & 13.898 & 489 \\
\hline 2008 & 1.337 & 24.759 & 6.712 & 16.293 & 493 \\
\hline 2009 & 352 & 24.051 & 5.530 & 12.348 & 498 \\
\hline 2010 & 431 & 25.886 & 7.532 & 13.005 & 517 \\
\hline 2011 & 428 & 26.798 & 8.403 & 14.637 & 530 \\
\hline 2012 & 430 & 27.308 & 8.483 & 14.635 & 543 \\
\hline 2013 & 284 & 28.027 & 8.380 & 15.170 & 552 \\
\hline 2014 & 306 & 28.189 & 8.684 & 16.199 & 549 \\
\hline 2015 & 473 & 29.462 & 8.987 & 15.852 & 542 \\
\hline 2016 & 461 & 30.389 & 9.418 & 16.161 & 521 \\
\hline 2017 & 758 & 31.871 & 11.054 & 18.134 & 475 \\
\hline
\end{tabular}

In order to achieve a correlation between the FDI and the observed indicators, it will be used regression analysis model ( PROGRAM IBM SPSS STATISTICs v22.0) is based on the indicators shown in Table 2. The regression analysis will determine the relationship between the observed variables and it should also be emphasized that this is a simple linear regression, and which we will apply to determine the individual relationships and relationships between FDI (independent variables) on the one hand and GDP, exports, imports and unemployment (dependent variables) on the other side.

Table 3.: Coefficients of determination between variables GDP-FDI

\begin{tabular}{|l|c|r|r|r|}
\hline \multicolumn{5}{|c|}{ Model Summary } \\
\hline Model & $\mathrm{R}$ & R Square & $\begin{array}{c}\text { Adjusted R } \\
\text { Square }\end{array}$ & $\begin{array}{r}\text { Std. Error of } \\
\text { the Estimate }\end{array}$ \\
\hline 1 & $.834^{\mathrm{a}}$ & .695 & .667 & 1.772046 \\
\hline $\begin{array}{l}\text { a. Predictors: (Constant), FDI mil. KM } \\
\text { b. Dependent Variable: GDP mil. KM }\end{array}$ \\
\hline
\end{tabular}

The table 3. shows the relationship between GDP as the dependent variable and FDI as the independent variables. The results reveal that $69,5 \%$ of GDP variance is explained by FDI variance, that is, $69,5 \%$ of GDP variable is determined by FDI variable. Based on the data obtained by the F-test $(\mathrm{F}=8,308$; $\mathrm{p}$ value $0,00)$, it can be concluded that the relationship between FDI and GDP is statistically significant, that is, the obtained coefficient of determination is not a coincidence because FDI can be statistically significant indicator in estimating the level of GDP in the years ahead. The following table 4. shows the indicators of regression analysis.

Table 4.: Indicators of regression analysis (GDPFDI)

\begin{tabular}{|c|c|c|c|c|c|}
\hline \multicolumn{6}{|c|}{ Coefficients $^{\mathrm{a}}$} \\
\hline \multirow[t]{2}{*}{ Model } & \multicolumn{2}{|c|}{$\begin{array}{l}\text { Unstandardized } \\
\text { Coefficients }\end{array}$} & $\begin{array}{l}\text { Standardized } \\
\text { Coefficients }\end{array}$ & \multirow[t]{2}{*}{$\mathrm{t}$} & \multirow[t]{2}{*}{ Sig. } \\
\hline & $\mathrm{B}$ & Std. Error & Beta & & \\
\hline \multirow{2}{*}{$\begin{array}{ll} & \text { (Constant) } \\
& \text { FDI mil. } \\
& \text { KM }\end{array}$} & 23.270 & 1.022 & & 22.77 & .000 \\
\hline & .011 & .002 & .834 & 5.007 & .000 \\
\hline \multicolumn{6}{|c|}{ a. Dependent Variable: GDP mil. KM } \\
\hline
\end{tabular}

The obtained coefficient $\mathrm{B}$ or $\beta$ indicates the way and how the series of independent variables influences the dependent and accordingly obtain an equation of regression that shows that an increase of FDI of one million results in a GDP increase of KM 0.011 million.

$\mathrm{Y}=23.270+0,011 * \mathrm{X}_{1}$

Figure 2 presents a histogram of the dependent variable GDP. Histogram is a graphical representation of the distribution of absolute or relative frequencies for a continuous statistical feature. On the horizontal coordinate axis, the interval classes are applied, and the absolute or relative frequencies are applied to the vertical coordinate axis, depending on the research requirements, and the we construct rectangles with heights of equal frequencies. 


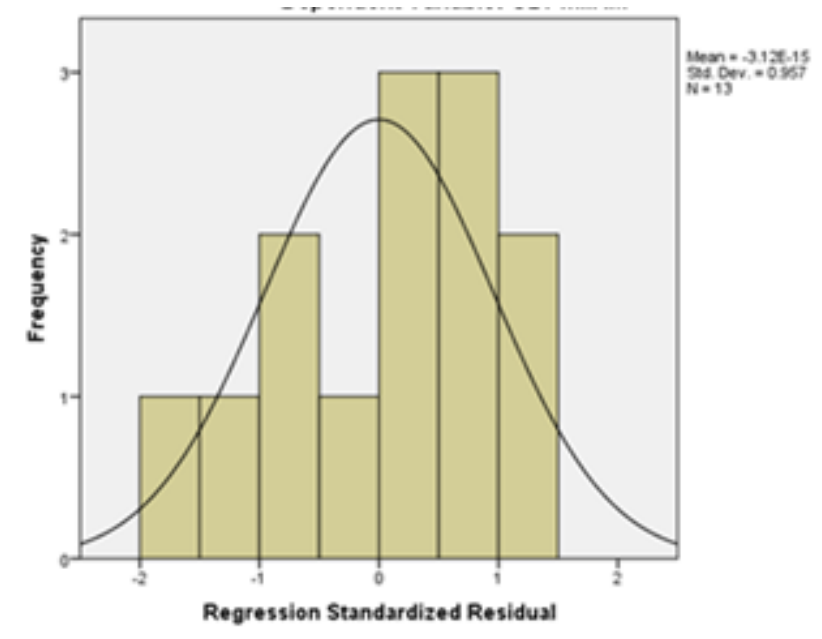

Figure 2: Histogram of the dependent variable GDP in mil. KM (Author 2018)

Table 5 shows the relationship between EXPORTS as dependent variables and FDIs as independent variables.

Table 5.: Coefficients of determination between variables EXPORT-FDI

\begin{tabular}{|l|l|l|l|l|}
\hline \multicolumn{4}{|l|}{ Model Summary } \\
\hline Model & R & R Square & $\begin{array}{l}\text { Adjusted } \\
\text { Square }\end{array}$ & $\begin{array}{l}\text { R } \\
\text { Std. Error of } \\
\text { the Estimate }\end{array}$ \\
\hline 1 & $.829^{\mathrm{a}}$ & .687 & .658 & .991268 \\
\hline $\begin{array}{l}\text { a. Predictors: (Constant), FDI mil. KM } \\
\text { b. Dependent Variable: Export mil. KM }\end{array}$ \\
\hline
\end{tabular}

According to obtained data in the table 5, it can be concluded that $68,7 \%$ of the variation of the dependent export is determined by the variation of the dependent FDI. Further analysis and results of F-test ( $p$ value $=0,000$ ) indicate that given indicators, coefficient of determination $\mathrm{R}^{2}$ and $\mathrm{B}$, that is $\beta$, are is statistically significant and we can conclude that FDI as the independent variable can be an adequate for indicator terms of export. The following table 6 . shows the indicators for regression analysis.
Table 6.: Indicators of regression analysis (EXPORT-FDI)

\begin{tabular}{|c|c|c|c|c|c|}
\hline \multicolumn{6}{|c|}{ Coefficients $^{\mathrm{a}}$} \\
\hline \multirow[t]{2}{*}{ Model } & \multicolumn{2}{|c|}{$\begin{array}{l}\text { Unstandardize } \\
\text { d Coefficients }\end{array}$} & $\begin{array}{l}\text { Standard } \\
\text {.Coeffic. }\end{array}$ & \multirow[t]{2}{*}{$\mathrm{t}$} & \multirow[t]{2}{*}{ Sig. } \\
\hline & B & $\begin{array}{l}\text { Std. } \\
\text { Error }\end{array}$ & Beta & & \\
\hline (Const.) & 5.970 & .572 & & & .000 \\
\hline $\begin{array}{l}1 \text { FDI mil. } \\
\text { KM }\end{array}$ & .006 & .001 & .829 & 4.909 & .000 \\
\hline
\end{tabular}

The equation of regression given in this analysis, as in previous case, shows that the increase of FDI results in increase of the export level in Bosnia and Herzegovina.

$\mathrm{Y}=5.970+0,006 * \mathrm{X}_{1}$

Figure 3. presents the histogram of the dependent variable export, ie the graphical presentation of the distribution of absolute and relative frequencies for a continuous statistical feature.

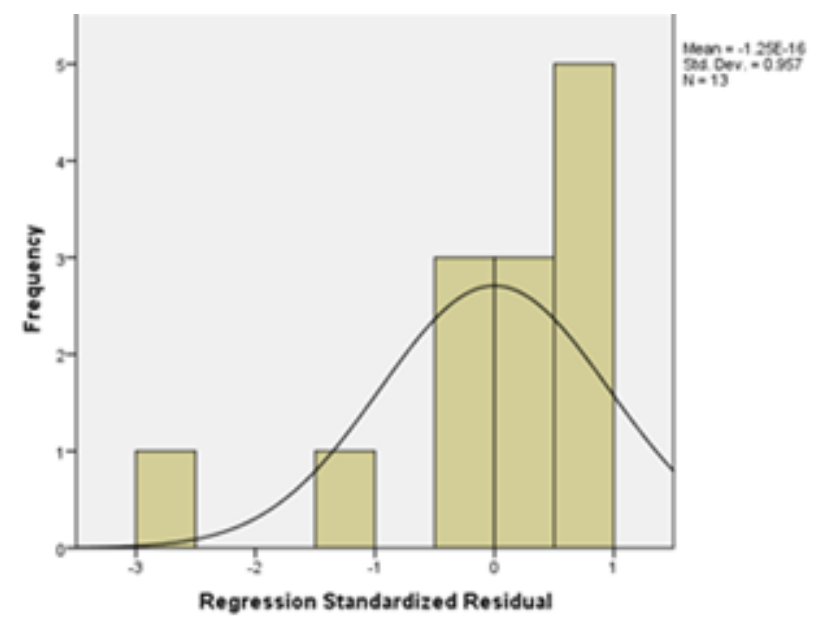

Figure 3: Histogram dependent variables EXPORT in mil. KM (Author 2018)

Table 7 shows the relationship between imports as dependent variable and FDIs as independent variable. 
Table 7.: Coefficients of determination between variables IMPORT-FDI

\begin{tabular}{|c|c|c|c|c|}
\hline \multicolumn{5}{|c|}{ Model Summary $^{\mathrm{b}}$} \\
\hline Model & $\mathrm{R}$ & R Square & $\begin{array}{c}\text { Adjusted R } \\
\text { Square }\end{array}$ & $\begin{array}{c}\text { Std. Error of } \\
\text { the Estimate }\end{array}$ \\
\hline 1 & $.489^{\mathrm{a}}$ & .239 & .170 & 1.583698 \\
\hline $\begin{array}{l}\text { a. Predictors: (Constant), FDI mil. KM } \\
\text { b. Dependent Variable: Import mil. KM }\end{array}$ \\
\hline
\end{tabular}

By analyzing the relationship between FDI and Import, based on the obtained results in the table 7, we can conclude that there is poor relationship between observed variables. Namely, only $23,9 \%$ of the variable import can be explained by variations of FDI . To be more specific, every change of FDI affects changes in import only by $23,9 \%$. Consequently, it was expected that there is statistical minimal significance of the relationship between these variables as evidenced by results of F-test $(\mathrm{p}$ value $=$ $0,09)$, which is something higher than the significance level $\alpha=0,05$. The following table 8 . shows the indicators of regression analysis.

Table 8.: Indicators of regression analysis (IMPORT-FDI)

\begin{tabular}{|c|c|c|c|c|c|}
\hline \multicolumn{6}{|c|}{ Coefficients $^{\mathrm{a}}$} \\
\hline \multirow[t]{2}{*}{ Model } & \multicolumn{2}{|c|}{$\begin{array}{c}\text { Unstandardized } \\
\text { Coefficients }\end{array}$} & $\begin{array}{l}\text { Standard. } \\
\text { Coeffici. }\end{array}$ & \multirow[t]{2}{*}{$\mathrm{t}$} & \multirow[t]{2}{*}{ Sig. } \\
\hline & B & $\begin{array}{l}\text { Std. } \\
\text { Error }\end{array}$ & Beta & & \\
\hline (Const.) & 13.944 & .913 & & $\begin{array}{c}15.26 \\
8\end{array}$ & .000 \\
\hline $\begin{array}{l}\text { FDI } \\
\text { mil. } \\
\text { KM }\end{array}$ & .004 & .002 & .489 & 1.859 & .090 \\
\hline
\end{tabular}

The relationship between variables is not statistically significant; it is clear that the obtained coefficients $\mathrm{B}$, that is $\beta$, are not statistically significant ( $\mathrm{p}$ value 0.09 ), and we cannot consider the SDI variable as an adequate predictor of import variable $\mathrm{Y}=13.944+0,004 * \mathrm{X}_{1}$
The equation of regression data in this analysis, as in the previous case, shows that the increase in FDI results in a slight increase in the level of imports in Bosnia and Herzegovina

Figure 4. presents the histogram of the dependent variable IMPORT, ie the graphical presentation of the distribution of absolute and relative frequencies for a continuous statistical feature

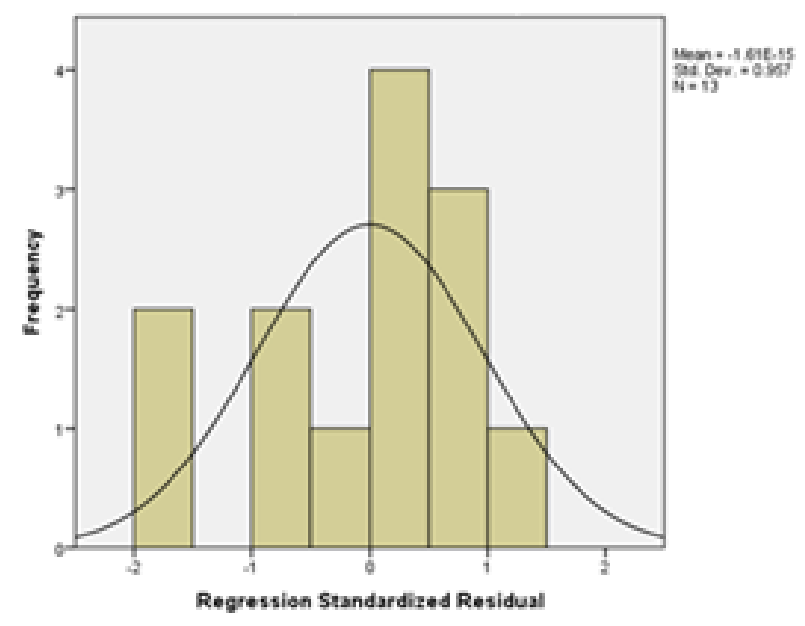

Figure 4: Histogram of dependent variable IMPORT in mil. KM (Author 2018)

Table 9 shows the relationship between unemployment in Bosnia and Herzegovina as dependent variables and FDI as independent variables.

Table 9: Coefficients of determination between variables UNEMPLOYMENT - SDI

\begin{tabular}{|l|c|r|r|r|}
\hline \multicolumn{5}{|c|}{ Model Summary } \\
\hline Model & $\mathrm{R}$ & R Square & $\begin{array}{c}\text { Adjusted } \\
\text { R Square }\end{array}$ & $\begin{array}{c}\text { Std. Error of } \\
\text { the Estimate }\end{array}$ \\
\hline 1 & $.164^{\mathrm{a}}$ & .027 & -.062 & 28.1873 \\
\hline \multicolumn{5}{|c|}{$\begin{array}{l}\text { a. Predictors: (Constant), FDI mil. KM } \\
\text { b. Dependent Variable: Number of unemploy 000 }\end{array}$}
\end{tabular}

Analyzing the relationship between FDI and Unemployment in Bosnia and Herzegovina, and based on the results obtained in Table 9, we can conclude that there is a weak link between the observed variables. Specifically, only $2.7 \%$ of the unemployment variation can be explained by variations in FDI. 
To be more precise, any change in FDI affects changes in unemployment in $\mathrm{B} \& \mathrm{H}$ only by $2.7 \%$. Consequently, there was no statistically significant relationship between these variables, as evidenced by the results of the Ftest (value $\mathrm{p} \mathrm{0.593),} \mathrm{which} \mathrm{is} \mathrm{significantly}$ higher than the significance level $\alpha=0.05$. The following table 10. shows the indicators of regression analysis.

Table 10: Regression Analysis Indicators (UNEMPLOYMENT - SDI)

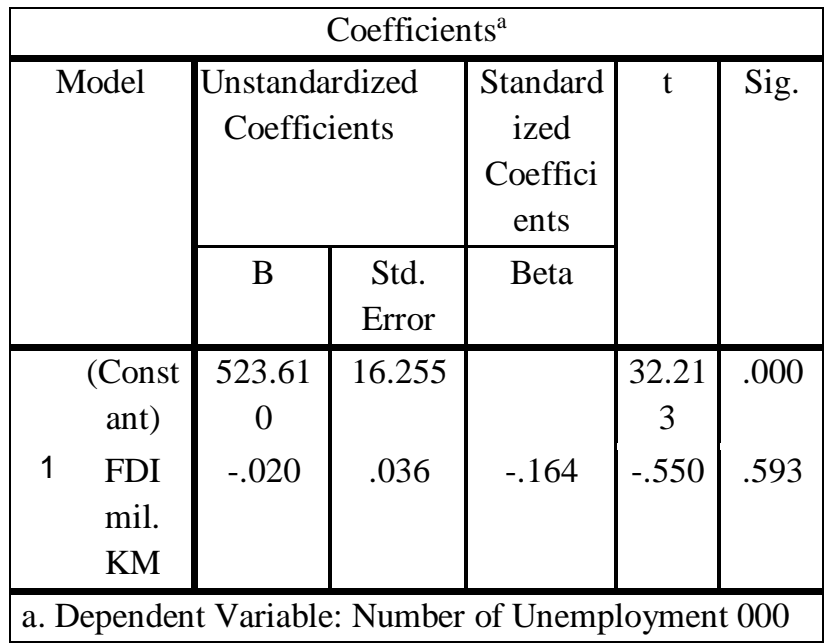

The relationship between variables is not statistically significant. It is clear that the resulting coefficients $B$, that is $\beta$, are not statistically significant ( $p$ value 0.593 ), and the SDI variable can not be considered an adequate variable for unemployment.

Statistical significance indicates that the relationship between the dependent variables is not random, but that there is a certain legitimate relationship represented by the equation of regression. In this analysis, the equation of regression is formed on the basis of the coefficient $\mathrm{B}$, as follows:

$\mathrm{Y}=523.610-0,020 * \mathrm{X}_{1}$

Based on the results presented by the equation of regression it can be concluded that the growth of foreign direct investment in $\mathrm{BiH}$ will lead to a decrease in unemployment (Figure 5).

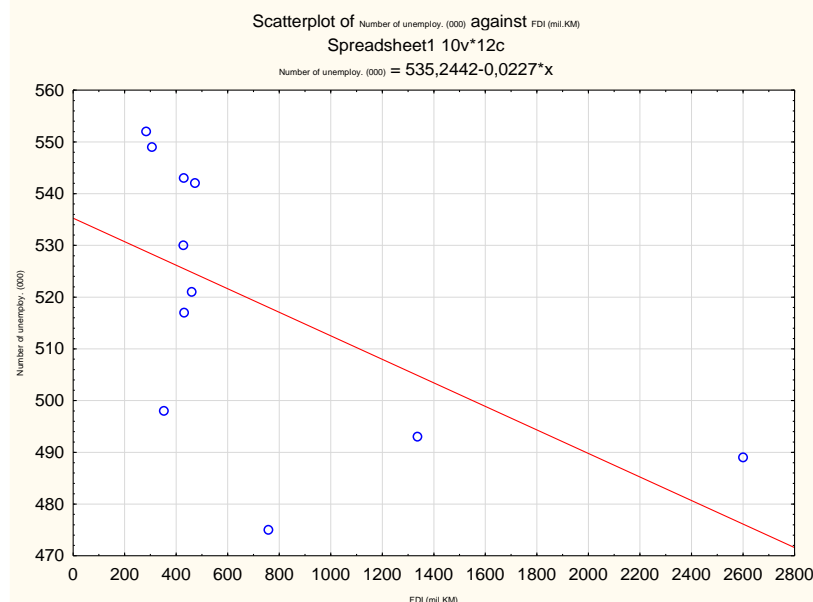

Figure 5. Graphic presentation of the regression function of UNEMPLOYMENT-SDI

Figure 6 presents the histogram of the dependent variable UNEMPLOYMENT, ie the graphical presentation of the distribution of absolute and relative frequencies for a continuous statistical feature. 


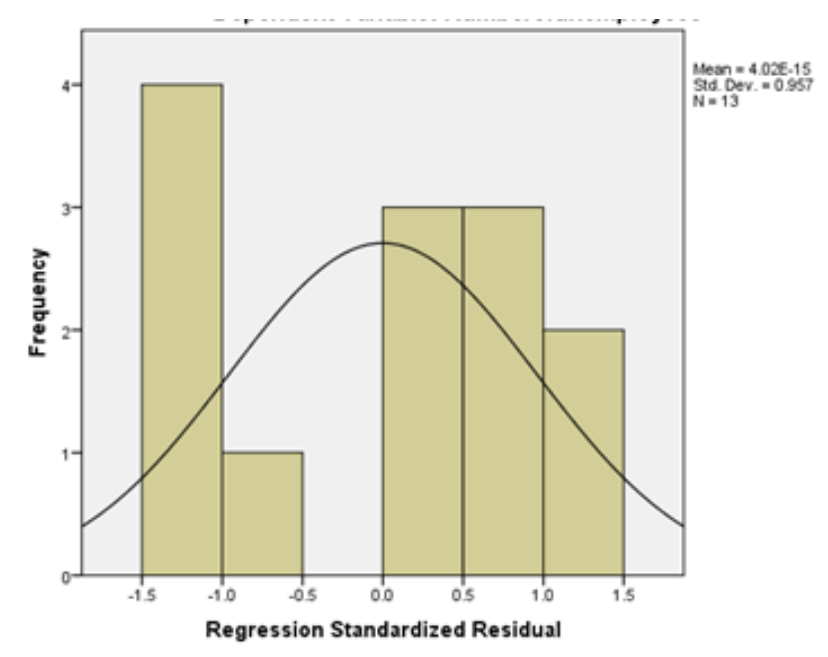

Figure 6: Variable Variable Histogram: Unemployment (in $000 \mathrm{KM}$ )

In order to complete the analysis and gain a better insight into the relationship between the observed variables, with the exception of regression analysis, it was necessary to make a correlation analysis that will provide information on the strength and method of aligning certain variables. Prior to the calculation of the correlation coefficient, a check of the normality of the position of the observed data was made using the statistical package 3B Stat and it was concluded that all variables do not have a normal position. This conclusion pointed to the need to calculate the Spearman coefficient of correlation (rho). In the following table 11., are listed, all calculated correlation coefficients by Spearman. 
Table 11.: Correlation coefficients of variables according to Spearman.

\begin{tabular}{|c|c|c|c|c|c|c|c|}
\hline \multicolumn{8}{|c|}{ Correlations } \\
\hline & & & FDI & GDP & Export & Import & $\begin{array}{l}\text { Number of } \\
\text { unemployed }\end{array}$ \\
\hline \multirow{15}{*}{$\begin{array}{l}\text { Spearman's } \\
\text { rho }\end{array}$} & \multirow{3}{*}{ FDI } & $\begin{array}{l}\text { Correlation } \\
\text { Coefficient }\end{array}$ & 1.000 & $.807^{* *}$ & $.829^{* *}$ & .376 & -.254 \\
\hline & & Sig. (2-tailed) & . & .001 & .000 & .206 & .402 \\
\hline & & $\mathrm{N}$ & 13 & 13 & 13 & 13 & 13 \\
\hline & \multirow{3}{*}{ GDP } & $\begin{array}{l}\text { Correlation } \\
\text { Coefficient }\end{array}$ & $.807^{* *}$ & 1.000 & $.978^{* *}$ & $.740^{* *}$ & -.028 \\
\hline & & Sig. (2-tailed) & .001 & . & .000 & .004 & .929 \\
\hline & & $\mathrm{N}$ & 13 & 13 & 13 & 13 & 13 \\
\hline & \multirow{3}{*}{ Export } & $\begin{array}{l}\text { Correlation } \\
\text { Coefficient } \\
\end{array}$ & $.829^{* *}$ & $.978^{* *}$ & 1.000 & $.735^{* *}$ & -.072 \\
\hline & & Sig. (2-tailed) & .000 & .000 & . & .004 & .816 \\
\hline & & $\mathrm{N}$ & 13 & 13 & 13 & 13 & 13 \\
\hline & \multirow{3}{*}{ Import } & $\begin{array}{l}\text { Correlation } \\
\text { Coefficient }\end{array}$ & .376 & $.740^{* * *}$ & $.735^{* *}$ & 1.000 & -.249 \\
\hline & & Sig. (2-tailed) & .206 & .004 & .004 & . & .413 \\
\hline & & $\mathrm{N}$ & 13 & 13 & 13 & 13 & 13 \\
\hline & \multirow{3}{*}{$\begin{array}{l}\text { Number of } \\
\text { unemployed }\end{array}$} & $\begin{array}{l}\text { Correlation } \\
\text { Coefficient }\end{array}$ & -.254 & -.028 & -.072 & -.249 & 1.000 \\
\hline & & Sig. (2-tailed) & .402 & .929 & .816 & .413 & . \\
\hline & & $\mathrm{N}$ & 13 & 13 & 13 & 13 & 13 \\
\hline
\end{tabular}

From the data presented in Table 11 above, it is obvious that FDI is the strongest correlation with exports (rho $=0.829$ ), then GDP (rho = 0.807 ), and weaker with imports (rho $=0.376$ ). Correlation is the weakest in unemployment (rho $=-0,254)$, it is insignificant and this ratio is indirect, i.e. that an increase in FDI leads to a fall in unemployment. The obtained data also indicate that this correlation coefficient is statistically extremely high for the ratio of GDP and exports (rho $=0.978$, and its sign indicates that GDP growth indicates an increase in exports to $\mathrm{BiH}$. The ratio of GDP and unemployment is low ( rho $=-0,028$ ), but with different indications, which leads to the conclusion that with GDP growth there is a decrease in unemployment, but the correlation coefficient between GDP and imports is positive and implies unemployment, but the correlation coefficient between GDP and imports is positive and implies that there is a direct link between these variables, which is statistically significant (rho $=0.740$ ) The relationship between exports and imports is direct and statistically significant, the rho correlation coefficient is 0.735 , and its sign shows that the growth of exports indicates an increase in imports in $\mathrm{BiH}$.

Also, the relationship between exports and unemployment is indirect (rho $=-0.072$ ), which leads to the conclusion that with the growth of exports there is a slight decrease in unemployment. 
The relationship between imports and unemployment is indirect (rho $=-0.249$ ), which leads to the conclusion that the growth of imports leads to a reduction in unemployment.

\section{CONCLUSION}

Foreign direct investment has one of the key roles in creating self-sustaining economic growth in Bosnia and Herzegovina. Foreign direct investments in Bosnia and Herzegovina amounted to $\mathrm{KM} 7,860$ billion in the period from 2007 to 2017, while foreign direct investments in the eight-year period (20102017) amounted to 3,571 billion KM. However, Bosnia and Herzegovina is not spared by the impact of the global financial crisis, whose consequences are, above all, visible in the real sector of the economy. Apart from having a negative impact on the financial and real sector, the global financial crisis has left a visible sign of the inflow of foreign direct investment in Bosnia and Herzegovina. Domestic factors such as slow economic growth and reduced inflows of foreign direct investment contributed to economic instability in Bosnia and Herzegovina. Apart from weak domestic demand, unfavorable external environment and political stalemate, poor macroeconomic, business and legal environment results hampered the economic recovery of Bosnia and Herzegovina.

The obtained results of the regression analysis relate to the strength, direction and statistical significance of the relationship between the observed variables. Regression analysis indicates that there is a statistically significant relationship between FDI and exports, FDI and GDP, as well as a weak link between FDI and unemployment. The obtained regression equations point to the conclusion that with the growth of FDI there is growth of GDP and exports, which is logical. In addition, the GDP-SDI correlation coefficient $($ rho $=0.807$ ) was obtained and pointed out that the growth of FDI corresponds to GDP growth. The EXPORT-SDI correlation coefficient (rho = 0.829) indicated that the growth of FDI corresponds to the growth of EXPORT. In contrast, the obtained equation of regression between FDI and unemployment indicates that the growth of foreign direct investment results in a reduction in unemployment. This assertion refers to the value of the correlation coefficient obtained (rho $=-0.254$ ). Further analysis of the correlation coefficient suggests that GDP growth has contributed to a slight reduction in new jobs and employment of labor, but slightly (rho $=-0,028$ ). The growth of exports did not lead to a significant development of the economy and the creation of new jobs (rho $=-0.072$ ). The relationship between imports and unemployment is indirect (rho $=0,249$ ), which leads to the conclusion that the growth of imports leads to a reduction in unemployment.

\section{REFERENCES}

1. Spulber, D.F. 2007. Global Competitive Strategy, Cambridge University Press, New York, str. 120

2. Stiglitz, J.E. Ocampo, J.A. Spiegel, S. Ffrech-Davis, R. Nayyar, D. 2006. Stability with Growth: Macroeconomics, Liberalization, and Development, Oxford University Press, New Yok, str. 37.

3. Kovačević, Radovan, 2000. Forms and mechanisms of foreign investments, Expert consulting-Foreign investments, Belgrade: University „Braća Karić“, March

4. Kovačević, Radovan 2011. International Finance, Belgrade 
(JPMNT) Journal of Process Management - New Technologies, International

Vol. 6, No 3, 2018.

5. BiH Council of Ministers, 2017 Bosnia and Herzegovina-Economic Trends, Sarajevo: Annual Reports 2007-2016.

6. Council of Ministers of $\mathrm{BiH}, 2013$. Bosnia and Herzegovina-Economic Trends, Sarajevo: Annual Report 2012

7. Foreign investment, 2000 Unbeyed „Braća Karić“ Belgrade, March

8. Council of Ministers of $\mathrm{BiH}, 2017$ Bosnia and Herzegovina-Economic Trends, Sarajevo: Annual Reports 2011-2016.

9. MIGA Annual Report, 2009. World Bank Group, Washington.

10. Republika Srpska Government, 2011. Economic Policy of Republika Srpska for 2012, Banja Luka, December

11. Ian, Ks. Su, Ks.G. 2009. Linearna regresijska analiza: teorija i računarstvo, svetsko naučno izdavaštvo, Nev Jersei Montgomeri D.C. Peck, E.A. Vining, G.G. Uvod u analizu linearne regresije

12. Petrović Ž., 2006. Business statistics, Banja Luka: University of Business Studies

13. Statistics Agency of $\mathrm{BiH}$ 2007-2017, http://www.bhas.ba

14. The Central Bank of BH (www.cbbh.ba) 